\title{
Writing the Self / Writing About the Self: "Auteur" and "Autruy" in Tabourot Des Accords' Les Bigarrures
}

\author{
CATHARINE RANDALL COATS
}

E stienne Tabourot Des Accords' Les Bigarrures (1588) is a compendium of games and word-plays. But it is also much more than that. For within the cataloguing format can be discerned instances in which Tabourot as author, rather than as mere compiler, appears. These irruptions can be elucidated through an examination of the four documents that introduce the text proper ("Théodecte T. au Seigneur Des Accords"; "Avant-propos de l'autheur"; "Andre Pasquet au lecteur", and the "Préface du Seigneur Des Accords"). Most fruitful in this regard, however, is an examination of a technique labelled by Des Accords the "adionctions". These latter appear to be commentaries, or glosses, upon the main texts. We shall demonstrate that these "adionctions" function, not to faithfully explicate a text, but rather to undermine the purported encyclopedic project of the Bigarrures, reorienting our perception of the text toward an awareness of Tabourot's singular creativity.

It would appear, from the intensity with which he discusses the presence of others' material (hereafter often referred to as "the other") in his own text, that Tabourot does not want the other, despite the fact that others are his main source. He experiences tension between his desire to compile a book, and his desire to write one and thereby divulge something of himself. His 'editor' in 'Au lecteur' expresses part of the problem: Et ne se devoit pas, à mon advis, l'autheur cacher, sous ombre qu'il estime le sujet si leger" (LB, vol. 1 16). Clearly, the editor feels more is going on in the text than mere frivolity and amusement. Francis Goyet, the editor of this edition of the Bigarrures, asserts that the 'editor' Tabourot posits is Tabourot's own mouthpiece: "[l'éditeur] André Pasquet [est] inconnu. Tout donne à penser qu'il s'agit de T[abourot] lui-même". "We know from other sixteenth-century writers that the ruse of a supposed editor was often employed to express concepts that the author 


\section{6 / Renaissance and Reformation}

himself did not feel at liberty to articulate. ${ }^{2}$ By incluing a letter from an acknowledged (although possibly fictional) editor, Pasquet, as well as writing a second sort of introdution to the text (that written, at least nominally, by Théodecte T.), Des Accords appears to create a situation of redundancy that, by the differences interior to the superficially similar pieces, suggests that, indeed, a program of writing (and of self-expression) distinct from the apparent motive of Les Bigarrures is being pursued. Tabourot makes further proof of his artistic duplicity when in the "Préface" he confesses, "Mais j'ay grand peur que cependant ... je parle des autres". (LB, vol. 123) The ruse of a fictional editor complicates our examination by also indicating that a certain amount of ambivalence exists towards admitting the desire to disclose the self.

The concern with the role of the 'other' is strongly represented in Les Bigarrures by two factors. The first is a long sequence of demurrals that occurs in the "Préface". By usurping a significant chunk of Tabourot's prologue, these disclaimers mimetically enact the tension between self and other that will underlie the entire text. For, instead of fulfilling the customary purpose of stating the author's plan of operation in the text, or acting as an introduction to the author himself, the first five pages of this eight-page preface are taken up with what others, rather than Tabourot himself, have to say. Tabourot begins by listing, at great length, all those things that others usually say in a preface, constantly deferring any revelation of what he himself intends to do. Indeed, he never does make such a statement, but by the time the reader unfurls the interminable recital of what Tabourot will not do, the reader forgets that Tabourot should have any program of his own. It is also significant that the solid block of subordinate clauses precludes any narrative grasp of the preface. In such a way will our reading of the Bigarrures be limited, at least the first time around, to skimming catalogued entries that possess no apparent narrative link. There are thematic groupings, but these suggest merely a potpourri of possibilities within each group, and do not lend themselves to the telling of a tale. These are not materials easily manipulated to achieve an author's purpose. For instance, Tabourot begins,

Encor que ce soit une façon ordinaire presque à tous ceux qui exposent quelque oeuvre en lumière, de choisir un certain personnage, afin de luy dédier ... Ou d'adresser quelque advertissement au Lecteur ... Ou bien se bastissent par imagination, de vaines raisons, qu'on leur peut, ce leur semble, obiecter ... (LB, vol. 1 19-20)

It is as though the prologue is designed specifically to block any reading of it. Any firm purchase on the paradigms it contains is denied, for the 
possibilities it begins to elaborate are never portrayed conclusively; the clauses never end, but rather sputter out without resolution, never achieving full sentence structure. Tabourot states that he intends never to imitate the substance or style of an other ("Je n'ay voulu toutesfois estre imitateur de telles façons de faire"LB, vol. 120 ), yet that is exactly what he does: he abdicates his voice, in the time and space of the text, to the other, or at least to a parody of the other. His statement of purpose is indefinitely postponed (and, unless we read between the lines, playing hide-and-seek with this coy author, is never revealed). Tabourot acts as though he has absolutely no self-investment in his text. He appears to leave his work open-ended, leaving the reader free rein to read, add to or subtract from, the book as he may so choose: "Mais je conseille à chacun de choisir seulement ce qu'il luy viendra à gré, et laisser le surplus" (LB, vol. 124$)$.

Yet, the "adionctions" strewn throughout the text provide indications that Tabourot is not being quite straightforward in this matter of textual selfeffacement. Tabourot suddenly becomes extrememly anxious as to what material the "adionctions" comment on, and where they are placed. Most worrisome to him is the question of who has written them (for there now seem to be two commentators, neither of whom is clearly identifiable as Tabourot himself: "Auteur" and "Autruy". It is "auteur" whom we would normally expect to represent Tabourot, and upon whom, because of his designation, we would ordinarily rely for clarification of the text. However, "auteur" is occasionally pre-empted by "autruy", causing a good deal of confusion on the reader's part between the two speakers and between text and gloss. "Autruy" has somehow finagled his way into the text, no longer as an outside authority or influence. He now seems rather to be an integral component of the work; indeed, he speaks for it. Tabourot's concern over the potential misrepresentation that may arise from the pretender's presence is evident in the "Avant-propos de l'autheur sur les impressions de ce livre". Here, Tabourot uncharacteristically acknowledges his role in composing the text. He makes the equation of textual and personal identity:

Le relisant ... je recognu incontinent et mon génie, et mon style du temps que je l'avois basty, pour me chatouiller moy-mesme, afin de me faire rire, le premier et puis après les autres. (LB, vol. 17 )

Here, his motivation in writing is to please himself, not others. Hence his choice of material is not indiscriminately encyclopedic; it is personally-inflected. The manner in which he presents it ("mon style") is subjective and unique. The Bigarrures is not just some heteroclitic composition, but some- 
thing he has carefully structured ("basty"). Because of the personal claim he makes on his text, Tabourot has two concerns. In this retrospective reading ("le relisant"), he finds that elements he stipulated to be incorporated into his text have been excised:

Mais le malheur a voulu que l'Imprimeur, auquel je l'[le surplus des Adjonctions] avois envoyé par les petits paperats, ne les a pas tous receu: ou, comme ie croy, les mit entre les mains de quelqu'un, que i'eusse bien voulu ne m'estre pas si familier en cest endroit, lequel les a retranché. (LB, vol. 18 )

Who is the thief, the "quelqu'un" or "autruy" of whom Tabourot speaks? We have no way of knowing definitely. Yet, two factors are suggestive of a psychological phenomenon. The progressive rapprochement of "autruy"'s style and content with that of the "auteur" so that they become virtually indistinguishable, and the ploy of pseudo-editor, point to the possibility that Tabourot is describing a schism within himself. He is fragmented into two personae, each of whom, initially, has a different conception of, and motive for, writing. The issue of point-of-view or perspective arises as early as the liminary piece to Les Bagarrures, "Théodecte T. au Seigneur Des Accords", in which a judiciously placed enjambement might be construed to mean that Des Accords portrays himself in his work:

Des Accords tes Bigarrures

Ressemblent les pourtraictures ... ${ }^{5}$

In addition, the writer of this letter speaks of the significance of the manner in which the material of the Bigarrures is arranged, and then viewed, as being a question of optics:

Le tout ...

Bien réduit selon l'Optique,

Au subiect d'un petit poinct,

qui les fait paroistre loing;

Se monstrant à nostre veue $\ldots{ }^{5}$

The writer hints that a disparity may exist between what the reader perceives and the true intention of the author. The reader's reaction, he suggests is that

... de variété plaisante,

En chasque endroit [le lecteur] retreuv[e]

Tousiours du contentement. ${ }^{6}$ 
The author, however, has a less frivolous, although unavowed and unexplicated, agenda. The letter addresses Des Accords, saluting him because he has composed Les Bigarrures

... sans toutesfois [se] distraire

Des actes plus sérieux ... ${ }^{6}$

The exact nature of these acts is not specified. But this letter, placed at the head of the text, may function to posit a paradigm of how the text should be read: by looking beyond its artful naivete to discern a larger authorial program implicit in it. We shall explore this possibility in more detail shortly.

The second concern Tabourot manifests is that not only has his text been manipulated without his permission, it has also been mutilated; further material - alien to his own composition or choice in compiling - has been inserted. Another voice speaks within his text:

au lieu [de mes adionctions], y a sabrogé des Adionctions de son stile, si peu correspondantes au mien, et esloignées de ma conception; qu'il est aisé à voir, à quiconque aura tant soit peu de jugement que cela n'est pas du mesme autheur ... Et autres infinis [exemples] montrent assez la diversité de mon stile au sien; et toutesfois je ne nieray pas qu'ils ne soient, peut estre, au goust de quelques uns, aussi bons que les miens. (LB, vol. 19)

An actual competitor is posited to Tabourot within Tabourot's own work. We note that there are four "adionctions" by the "auteur" to seven by "autruy". Because "autruy" exists as a rival to "auteur", Tabourot fears that the commentaries of "auteur" may be more appealing to the reader, who is now given a choice between two modes of expression in the text. Tabourot here seems to suggest a schism of self such we have already postulated; how else could he view "autruy" as possessing an existence separate from his own (which he dubs "auteur")? "Auteur" and "autruy" may epitomize respectively the pedantic and the salacious aspects of the personality of Tabourot himself. This possibility is substantiated by the fact that Tabourot's ambivalence towards this other person, or other manifestation of himself, is at times manifested in hostility and resentment, while elsewhere the ambivalence is mollified by conciliation. He states,

... et comme aussi j'ay sceu que c'est quelque docte personnage, qui ne m'a point fait de malice ces Adionctions, ie ne les ay pas voulu oster ny m'estonner à lencontre de luy. (LB, vol. 110$)$ 
Emphasizing differences in style, Tabourot attempts to separate out that which he intended to say from that which an 'other' has said ("j' ay voulu estre plus courtois envers mon faiseur d'Adionctions qu'il n'a esté envers moy, car j'ay séparé ses Adionctions ... et les mises à la fin des miens" (LB, vol. 112), but he does not have great success in this endeavour. For, we note that the "adionctions" gradually blur in style, so that those coming after - supposedly those of the other - take on the author's idiom, and those of the author assume the tenor of the other. This progressive confounding of identities is heightened by the clear, distinct, even opposing personalities of "auteur" and "autruy" as originally formulated.

The Bigarrures thus becomes, for its own author, an unusual and threatening construction. Tabourot's books cannot represent his self-concept or, at least, not in any conventional, unified and univalent fashion, since two voices - one of them presented as illegitimate - are at war in the text. Composition procedes by disjunction and conflict rather than through the smooth accruement of portrayal and self-commentary. In order to determine the identity of the author, we must examine both voices whose dissonance is inscribed within the text. It is perhaps within the space of a dialectic relationship between the two speakers that authorial presence will be discerned.

The discernment of the oscillation between "autruy" and "auteur" becomes a sort of metatext, a continuous commentary on the construction of the text that becomes itself of more importance than the text's contents. The "adionctions" are nearly always placed near the end of the chapters; however, it is not clear why they close some chapters but are omitted in others. Initially, "auteur" makes a straightforward commentary on the preceding text. At the end of a chapter entitled "Des Rebus de Picardie", for example, the "adionction" is identified as "de l'autheur". We must first ask why this identification of authorship is required. Since "autruy" has not yet made his appearance in the text, who else but the author could have written the "adionction"? At any rate, the "adionction" observes

\footnotetext{
L'Aretin en certaine Comédie introduit un Zazin, qui se moquant des devises Rebussiés de son temps, disoit qu'il porteroit pour la sienne, un hain, un dauphin, et un coeur, pour signifier, "Hamo, delfino, cuore:/Amo del fino cuore." 9
}

The tone is didactic, neutral and informative. Rather than interpreting preceding material, these early "adionctions" seem designed simply to convey, with the authorial imprimatur, additional examples appropriate to each 
chapter heading. The "adionctions" at this stage obscure, rather than unveil, any authorial personality. He becomes but one compiler among many. "Auteur" 's observations are characterized by scholarly qualification. Yet, early on, "Auteur" 's reliability can be called into question; his commentaries are often farcical or even misleading. As regards the example just cited, editor Goyet notes that

je n'ai vu comédie de l'Aretin qui ait un "zani" pour personnage. ${ }^{4}$

"Auteur" also becomes increasingly less serious. My parenthetical remarks begin to sketch out the margins within which "auteur" will begin to exhibit some of the attributes of "autruy". For example, in the chapter entitled "Des Equivoques Latins-Français", the "auteur" offers this explanation of terminology: "Et les parisiens pour dire en Latin un vieux pot, l'appellent potentiam, tout en un mot, quasi pot ancian ou ancien". (LB, vol. 1 51)

The personality of "autruy" differs from the early manifestations of "auteur". "Autruy" is initially typified by crude pleasantries or obscenities. In "Des Equivoques Français", he jokes, "Car compromis, qu'est-ce autre chose qu'une fille qui est fiancée", while in the next chapter he speaks of prostitution and fornication:

... une bonne Drôlesse, qui couroit galamment l'esquillette. (LB, vol. 1 51)

Midway through the work "autruy" becomes more literary in his preoccupations "Bien élégant et industrieusement enchesné est l'Epigramme pastoral ... du gentil Du Bellay" (LB, vol. 1 147) at about the same time that "auteur" adopts a more salacious style of speech, formerly typical of "autruy". By the time of the section, "Des Epitaphes", however, we find "autruy" talking in a learned vein about the poetry of Thomas More:

Celuy m'a bien pleu autrefois, que j'ay leu les Poëmes de Thomas Morus, Chancelier d'Angleterre, qu'il fit ... sur la mort d'un chantre ... (LB, vol. 1 224)

while "auteur" tells dirty jokes:

divine vieille Péteuse, qui mourut en pétant ... (LB, vol. 1 224-5)

As "auteur" abandons his literary role in favor of a joking, bawdy persona, he becomes less defined and less assertive. For instance, he confesses to uncertainty as to the appropriate attribution of games or quotes used in the 
text: "l'Auteur est incertain du suivant ..." (LB, vol. 1 144), undermining thereby the notion that a specific authorial selection has been guiding to the construction of the text. He further distances himself from any recognition or acknowledgement of his role as author by citing himself in the third person, as an occasional source for some of the witty sayings:

Entre les oeuvres de Virgile, je void sur l'Epitaphe d'un incertain autheur, aussi docte et naïf, qu'on sçauroit souhaiter ... Monsieur Tabourot, Official à Langres, l'a ainsi miraculeusement traduit, en ces deux alexandrins. (LB, vol. 1 146)

Such unavowed self-citations act in two contemporary ways which mirror the dialectic we are positing between "auteur" and "autruy". First, quoting oneself in one text as though one did not know oneself is a way of disavowing the role of the self. Yet, the strategy of self-citation has been effectively employed elsewhere in the sixteenth-century ${ }^{5}$ to strengthen the multivocal resources of the author and to multiply the occasions in which it is possible for him to be present. We must search further to determine how Tabourot intends this strategy to work here. Further, the third person attribution is confusing for the reader, for if Tabourot is spoken of in the third person, who is the 'je' who speaks in, organizes and presents the text? A dialectic is inaugurated in that at the very moment that authorship is denied, the author's persona surreptitiously creeps into the text.

At the same time that the author may be said to be seen working to subvert the other's project and reclaim his text, the appearances of "autruy" become increasingly lengthy and frequent. "Autruy" begins to appear twice as often as the "auteur". Indeed, in some chapters there is no "adionction" by "auteur", but then two in a row by "autruy", each labelled as his (LB, vol. 1 170). This phenomenon produces an even more cut-and-paste appearance in the already mosaic-like structure of the Bigarrures, as though two statements by "autruy" have been taken from different places and juxtaposed without thought for redundancy or complementarity. Such predominance of "autruy" also creates a physical, textual mass that begins to usurp "auteur"'s space.

Coherent authorship is menaced thereby; Des Accords fears that his selfexpression will always be pre-empted by the other. Yet this prevalence of the other, paradoxically, is made possible through Tabourot's own agency, for the strategy of the composition of the Bigarrures has been, throughout, to borrow others' materials. Speaking of the ultimate in Renaissance poetry that 
Imitation raises a man above himself, leads him to self-forgetfulness and prevents his return to basic self-hood, discolors his native purity by an osmosis of otherness. ${ }^{6}$

Tabourot similarly expresses a fear of personal amorphousness that is translated by an inability at any given moment to say who he is: "a présent, ... si je suis dissemblable à celuy que j'estois alors". (LB, vol. 1 11) He would prefer that "l'autheur soit toujours semblable à soy", but by playing off "auteur" and "autruy", with "autruy" progressively assuming the authorial role, Tabourot mimes his concern that such integrity is impossible.

Given the multi-faceted interaction between "auteur" and "autruy", how is the reader to ascertain the identity of the 'je' speaker who concludes the book? This 'je' follows upon an "adionction de l'auteur" and an "adionction d'autruy", in that order. The "adionction d'autruy" appears closed: it is labelled "fin de l'adionction". But then 'je' begins to speak. Significant for our thesis that "autruy" and "auteur" may be Janus-like aspects of one personality is that " $\mathrm{je}$ " is a composite of attributes both of the "auteur" and of "autruy". He speaks authoritatively about his literary technique:

Je te prie, Lecteur, prendre cependant de bonne part, ce que je t'ay icy ramassé, et pense que si je voulois, j'ay assez de matière, de faire un gros livre." (LB, vol. 1235$)$

But he also follows these remarks with facetious comments more typical of what initially had been "autruy"'s style:

Or après icelles, $\mathrm{j}$ 'espère bien à la suite de ces Discours faire paroistre de quelles viandes je sçay traiter mes hostes. Cependant, comme pour entrée de table, ie te donne ces petites fricassées, ces pastez de chair hachée, et ces potages de marmite de College ... tu auras après des viandes plus solides (LB, vol. 1236 ).

The abundant and sufficient 'matière' he has just exalted is now become bits and oddments of a banquet feast. The comparison of Les Bigarrures to assorted hors-d'oeuvres before a main course in some measure devalues the work, rendering it a mere appetizer to the substantial meal to come ("des viandes plus solides"). Contrarily, the hors d'oeuvres motif plays an essential role, that of delectable invitation, spreading an ample board to hosts eager to dip into the feast (and text). "Je" is not an absolute authority, but rather encourages a co-production of his next text between writer and reader; this work is intentionally left open (it is called the "premier livre") and he speaks 
of a projected "suite de ces Discours" (LB, vol. 1 236). Earlier in Les Bigarrures Tabourot invited the reader to make of this text what he will, to tailor it as suits him:

Car chacun adioustera ceux qu'il luy plaira à ce papier blanc (LB, vol. 1110$)$. Si le lecteur en trouve quelqu'un en ces oeuvres, il pourra icy faire adiouster. (LB, vol. 1 172)

Ironically, however, there is no white page or blank space available; the book is jammed full. We consequently wonder to what extent Tabourot truly desires the involvement of the reader in his text. Typically, Tabourot is ambivalent here, too. He seems to be calling for a more organic conception of a text one that evolves dialectically in the interaction between "auteur" and "autruy", who themselves may be taken as figures of the writer and the reader. Rather than fearing autruy/reader and worrying lest there be no space for himself in the text, Tabourot now graciously makes room for the other. "Autruy" is made to play an accessory, albeit supplementarily creative, role in "auteur"'s grander scheme. "Auteur" can use "autruy" to take his book in entirely new directions, thereby legitimizing a plurality of authorial projects. "Auteur"'s role originally demonstrated more imitatio than composito:

Ce qui s'ensuit est extrait d'un epistre, envoyée à l'Auteur par un sien amy". (LB, vol. 1110 )

Now, however, the voice of "autruy" is licensed within the text "auteur" appropriates it, bringing to his idiom a more unbridled - and hence, potentially more original - form of expression. In that sense, the concluding remarks to Les Bigarrures are emblematic of Tabourot's desire to transcend the technique of imitatio in favor of a more independent text. He first rehearses his former imitative acts, citing possible authorities for his text: ("pour entre-colliger un livre gros comme un Calepin ... tu as ... Marule, Jean Second, Politian, le Vézéleien ... - LB, vol. 1 235), but he then surpasses such reliance on others' saying in favor of his own textual autonomy, demonstrating that the materials he has selected to form his text have been transformed into his own unique sense through his act of appropriation:

Parquoy ne vas point te vanter et dire, $\mathrm{O}$ j'en sçay de meilleurs, il n'a pas tout mis, il a oublié cestuy-ci, cestuy-là. Car, l'ay-je fait sciemment. (LB, vol. 1 235-6; my italics) 
This apparently imitative text is actually one that acts out the steps leading to its assumption of autonomy: "it acts out its own coming into being." Camouflaging itself as a compendium of games to be played, the text itself plays a game with its reader. The reader must seek the presence behind and within the interplay of "auteur" and "autruy". That is, rather than being composed of games, the text is composed through a game. This is a game of interpretation and discernment of authorial identity. Tabourot, his own first reader, is himself the first to play this game when, as he alerts us, he stumbles upon his manuscript and must reread it before sending it to a printer before Tabourot can recall exactly what he intended when he composed the Bigarrures.

Occasion dequoy j'ai releu ce folastre livre de bout à autre, ce que jamais auparavant je n'avois fait, afin de le remetrre en lumière, selon ma vraye conception. (LB, vol. 111 ; my italics)

So does "auteur", hidden within the text and sought by the reader, constitute himself within the games in, and the games of, the text.

Ultimately, the final product of this role switching between "auteur" and "autruy", the reliance on games others have previously played, and the furtive entrance of 'je' into Les Bigarrures is a highly sophisticated parody of the humanist technique of imitatio. The parody points to a desire to move beyond the traditional compositional technique. Thomas Greene observes that

It would be surprising if there had been no hostility toward the pressure to imitate. Fortunately for the health of ... [the] national culture, there was a good deal ... Was there a humanist will not to absorb, a sophisticated, refined fear or antagonism toward the buried, gigantic remains? Undoubtedly there was ... The process called imitation was not only a technique or a habit; it was also a field of ambivalence, drawing together manifold, tangled, sometimes antithetical attitudes. ${ }^{8}$

Despite its apparently derivative character, the Bigarrures makes a statement for authorial presence and original expression. The inclusion of enormous blocks of borrowed material results in a parody ${ }^{9}$ of the manner in which humanist writers rely too extensively on the utterances of revered predecessors ${ }^{10}$. The zones in Les Bigarrures in which shifts in voice and reliability transpire between "auteur" and "autruy" ultimately attest to the progressive liberation of authorial consciousness from the shadow of the 'other' - the other writer, the freer speaker, the competitor for authority. The "auteur" is 
eventually emboldened to speak in a style as witty and as bawdy as that of the citations upon which he had formerly relied for a vicarious mouthpiece.

In this sense, the games of which Les Bagarrures is composed exact a larger, more comprehensive games-playing from the reader. Not only are all the games in the text played through the reading act, which in seeking to comprehend them must play by their rules, but also the text itself is constituted as a game in which the construction of a new text - from, and beyond existing components - is mimed and played. Les Bigarrures, the compendium, becomes secondary to Les Bigarrures, a testimony to the multifaceted, yet individual and authorial intervention of Des Accords.

\section{Columbia University}

\section{Notes}

For the purposes of this study, the following text was used throughout: Estienne Tabourot Des Accords, Les Bigarrures du Seigneur Des Accords, ed. Francis Goyet. TLF (Geneva: Droz, 1986). All further references in the text are to this edition.

1 Goyet, vol. 2 \& 3.

2 D'Aubigné uses such a strategy in Les Tragiques, stating in "Aux Lecteurs" that an editor has snatched d'Aubigné's writings from the fire in which the author intended to destroy them: "Voicy le larron Promothée qui, au lieu de grace, demande gré de son crime ... comme ayant desrobé pour vous ce que son maistre desroboit". 5

3 Goyet, vol. 2, VAR F, p. 18.

4 A similar interplay occurs between d'Aubigné's Histoire universelle and Sa vie à ses enfants.

5 Thomas Greene, The Light in Troy: Imitation and Discovery in Renaissance Poetry (New Haven: Yale University Press, 1982), 277.

6 Greene, 41.

7 Greene, 43-5.

8 Such parodies can be found elsewhere in the French Renaissance. Le moyen de parvenir, in which Béroalde creates an intentionally confusing text in order to parody a dangerous tendency in humanism - the hierarchization of knowledge - is one example. Cf. Catharine Randall (Coats), "Two Suggestions for A New Reading of the Moyen de parvenir, Neophilologus, 72 (1988), 10-16.

9 Montaigne confesses that his work is thoroughly dependent on the writings of Plutarch and Seneca. Cf. Greene, 45. 